\title{
HUBUNGAN KARAKTERISTIK BALITA, PENGETAHUAN IBU DAN SANITASI TERHADAP KEJADIAN STUNTING PADA BALITA DI KECAMATAN LABUAN KABUPATEN PANDEGLANG
}

\author{
Siti Nur Ramdaniati, Dian Nastiti \\ Program Studi Kesehatan Masyarakat, Fakultas Sains Farmasi dan Kesehatan, Universitas Mathla'ul Anwar Banten, Email : \\ siti.nurramdaniati@gmail.com
}

\begin{abstract}
Abstrak
Stunting adalah kondisi gagal tumbuh pada anak balita (bayi di bawah lima tahun) akibat dari kekurangan gizi kronis sehingga anak terlalu pendek untuk usianya dan memiliki risiko terjadinya penurunan kemampuan intelektual serta peningkatan risiko penyakit degeneratif di masa mendatang. Tujuan penelitian ini untuk mengetahui hubungan karakteristik balita, pengetahuan ibu dan sanitasi terhadap kejadian stunting. Rancangan penelitian ini case control dengan populasi seluruh balita stunting (39 balita). Penelitian ini menggunakan metode total sampling dengan jumlah 39 kasus dan 39 kontrol. Data dikumpulkan dengan wawancara menggunakan kuesioner dan antropometri untuk mengukur tinggi badan. Pengolahan data menggunakan analisis univariat dan analisis bivariat. Hasil analisis menyimpulkan bahwa terdapat hubungan signifikan antara Berat Badan Lahir Rendah (BBLR), pengetahuan ibu, kepemilikan jamban dan sumber air terhadap kejadian stunting pada balita di Kecamatan Labuan. Pihak Puskesmas sebaiknya melakukan kelas ibu balita dan ibu hamil secara berkala serta kegiatan pemberdayaan masyarakat dalam kepemilikan jamban dan sumber air bersih.
\end{abstract}

Kata kunci : stunting, balita, labuan

\section{Pendahuluan}

Stunting adalah kondisi gagal tumbuh pada anak balita (bayi di bawah lima tahun) akibat dari kekurangan gizi kronis sehingga anak terlalu pendek untuk usianya. Menurut Kementrian Kesehatan stunting adalah anak balita dengan nilai z-scorenya kurang dari -2 s/d standar deviasi (stunted) dan kurang dari 3sd (severely stunted). Kondisi anak pendek adalah tanda dari adanya masalah pertumbuhan. Apalagi, jika stunting dialami oleh anak yang masih di bawah usia 2 tahun. Hal ini harus segera ditangani dengan segera dan tepat karena stunting adalah kejadian yang tidak bisa diperbaiki jika sudah terjadi.

Kondisi stunting disebabkan oleh tidak tercukupinya asupan gizi anak, bahkan sejak masih di dalam kandungan. World Health Organization (WHO) menyatakan bahwa $20 \%$ kejadian stunting sudah terjadi ketika bayi masih berada di dalam kandungan, sehingga dapat mengakibatkan berat bayi lahir rendah (WHO, 2014). Penelitian Paudel tahun 2012 di Nepal menunjukan bayi dengan berat lahir rendah mempunyai resiko lebih tinggi menjadi stunting. Panjang lahir bayi juga berhubungan dengan kejadian stunting. Faktor lain yang berhubungan dengan stunting adalah asupan asi ekslusif pada balita. Penelitian Ethiopia Selatan membuktikan bahwa balita yang tidak mendapatkan asi eksklusif selama 6 bulan beresiko tinggi mengalami stunting (Fikadu et.al, 2014). Adanya penyakit infeksi dapat memperburuk terjadinya stunting.

Menurut WHO prevalensi stunting dikatakan tinggi apabila mencapai 30\% - 39\% dan dikatakan sangat tinggi jika prevalensinya 
mencapai $\geq 40 \%$. Berdasarkan Riset Kesehatan Dasar (Riskesdas) Tahun 2013, prevalensi stunting di indonesia termasuk dalam kategori tinggi yaitu 37\%. Prevalensi meningkat secara nasional dalam tiga tahun 2010 - 2013 sebanyak 1,6\%. Angka prevalensi tersebut masih lebih tinggi di bandingkan angka prevalensi gizi kurang dan buruk $(17,9 \%)$, kekurusan (13,3\%) serta kegemukan (14\%) (Kemenkes, 2014). Berdasarkan hasil Pemantauan Status Gizi menggunakan Indeks $\mathrm{TB} / \mathrm{U}$ di Indonesia Tahun 2016, sebanyak 8,5\% balita mempunyai status gizi sangat pendek dan $19,0 \%$ balita mempunyai status gizi pendek. Hasil PSG Tahun 2017 mengalami peningkatan sebanyak $9,8 \%$ balita mempunyai status gizi sangat pendek dan $19,8 \%$ balita mempunyai status gizi pendek (Kemenkes, 2018).

Dilihat dari indikator Masalah Kinerja Program Gizi Provinsi Banten, terjadi peningkatan persentase kejadian stunting. Pada tahun 2016 persentase kejadian stunting hanya 27,0\% (Kemenkes, 2017). Sedangkan pada tahun 2017 sebesar 29,6\%. Hal tersebut juga terjadi di Kabupaten Pandeglang dimana kasus balita stunting pada tahun 2016 sebesar 35,3\% dan tahun 2017 meningkat menjadi $37,8 \%$. Kabupaten Pandeglang mencakup 36 kecamatan. Kecamatan Labuan merupakan salah satu kecamatan di Pandeglang yang memiliki jumlah balita stunting tertinggi kedua setelah Kecamatan Mekar Jaya. Berdasarkan data dari Dinas Kesehatan Pandeglang pada tahun 2017 terdapat 69 balita yang mengalami stunting (Dinkes Kab Pandeglang, 2018). Penelitian tentang determinan kejadian stunting di wilayah ini juga belum pernah dilakukan. Oleh karena itu, peneliti ingin mengetahui faktor risiko kejadian stunting pada balita (0-59 bulan) di wilayah kerja Puskesmas Labuan, Kabupaten Pandeglang, Banten.

\section{Metode}

Penelitian ini merupakan penelitian analitik observasional, dengan rancangan case- control. Kasus adalah balita (0-59 bulan) yang mengalami stunting dan kontrol adalah balita (0-59 bulan) yang tidak mengalami stunting. Populasi adalah seluruh balita yang berusia 0-59 bulan di Kecamatan Labuan pada saat penelitian dilakukan. Penelitian ini menggunakan Total Sampling dari kasus stunting yang ada di wilayah Kecamatan Labuan sebanyak 39 balita dan juga kelompok kontrol (balita tidak stunting) sebanyak 39 balita. Jadi jumlah sampel dalam penelitian ini sebanyak 78 balita dengan perbandingan kelompok kasus dengan kelompok kontrol sebesar 1:1.

Variabel yang diteliti meliputi karakteristik balita (ASI Eksklusif, status BBLR dan imunisasi dasar), pengetahuan ibu tentang gizi dan sanitasi (kepemilikan jamban dan air bersih). Data dikumpulkan dengan wawancara menggunakan instrument kuesioner dan mengukur tinggi badan dengan menggunakan antropometri. Data diolah dengan menggunakan analisis univariat dan analisis bivariat dengan menggunakan uji statistic Chi-square.

\section{Hasil}

\section{Analisis Univariat}

\section{Stunting}

Menurut Kementrian Kesehatan balita dikatakan stunting jika memiliki nilai zscorenya kurang dari -2 sd standar deviasi (stunted dan kurang dari - 3sd (severely stunted). Kedua kategori tersebut termasuk stunting.

Tabel 1. Distribusi Frekuensi Stunting Pada Balita di Kecamatan Labuan

\begin{tabular}{lcc}
\hline \multicolumn{1}{c}{ Variabel } & F & \% \\
\hline Kasus (Stunting) & 39 & $50 \%$ \\
Kontrol (Normal) & 39 & $50 \%$ \\
\hline Total & 78 & 100 \\
\hline
\end{tabular}

Berdasarkan tabel 1 dapat diketahui bahwa dari 78 responden, terdapat 39 balita yang mengalami stunting dan 39 balita normal (tidak mengalami stunting). 


\section{Karakteristik Balita}

Pada penelitian ini, karakteristik balita yang diteliti meliputi variabel ASI eksklusif, Berat Badan Lahir Rendah (BBLR) dan status imunisasi dasar.

Tabel 2. Distribusi Frekuensi Karakteristik Balita di Kecamatan Labuan

\begin{tabular}{lcccc}
\hline \multirow{2}{*}{\multicolumn{1}{c}{ Variabel }} & \multicolumn{2}{c}{ Kasus } & \multicolumn{2}{c}{ Kontrol } \\
\cline { 2 - 5 } & F & \% & F & $\%$ \\
\hline ASI Eksklusif & & & & \\
Tidak & 15 & 38,4 & 14 & 35,9 \\
Ya & 24 & 61,6 & 25 & 64,1 \\
\hline Total & 39 & 100 & 39 & 100 \\
\hline BBLR & & & & \\
Ya & 11 & 30,7 & 0 & 0 \\
Tidak & 28 & 69,3 & 39 & 100 \\
\hline Total & 39 & 100 & 39 & 100 \\
\hline Imunisasi Dasar & & & & \\
Tidak & 6 & 15,4 & 2 & 5,1 \\
Ya & 33 & 84,6 & 37 & 94,9 \\
\hline Total & 39 & 100 & 39 & 100 \\
\hline
\end{tabular}

Berdasarkan tablel 2 diketahui bahwa balita yang tidak mendapatkan ASI eksklusif proporsinya hampir sama antara kelompok kasus dan kontrol yaitu 15 balita kelompok kasus dan 14 balita kelompok kontrol. Selain itu dapat diketahui juga bahwa balita yang mengalami Berat Badan Lahir Rendah (BBLR) seluruhnya merupakan kelompok kasus (11 balita) dan balita yang tidak mendapatkan imunisasi dasar sebagian besar merupakan kelompok kasus.

\section{Pengetahuan Ibu}

Pada variabel pengetahuan ibu, terdapat 15 pertanyaan tentang gizi yang dapat kita lihat distribusi jawaban yang benar dan salah pada tabel 3 dibawah ini :

Tabel 3. Distribusi Frekuensi Jawaban Benar Pengetahuan Ibu Tentang Gizi Balita

\begin{tabular}{|c|c|c|c|c|}
\hline \multirow{2}{*}{ Pertanyaan } & \multicolumn{4}{|c|}{ Jawaban } \\
\hline & B & $\%$ & $\mathbf{S}$ & $\%$ \\
\hline Asupan bayi 0-6 bulan & 50 & 64,1 & 28 & 35,9 \\
\hline Pengertian ASI Eksklusif & 43 & 55,1 & 35 & 44,9 \\
\hline Lama Pemberian ASI & 55 & 70,5 & 23 & 29,5 \\
\hline $\begin{array}{l}\text { Acuan Pemberian } \\
\text { Makanan Pada Balita }\end{array}$ & 50 & 64,1 & 28 & 35,9 \\
\hline $\begin{array}{l}\text { Zat gizi yang dibutuhkan } \\
\text { untuk pertumbuhan }\end{array}$ & 55 & 70,5 & 23 & 29,5 \\
\hline Sumber Karbohidrat & 37 & 47,4 & 41 & 52,6 \\
\hline Sumber Zat besi & 33 & 42,3 & 45 & 57,7 \\
\hline Sumber protein & 53 & 67,9 & 25 & 32,1 \\
\hline Akibat kekurangan gizi & 71 & 91 & 7 & 9 \\
\hline Makanan gizi seimbang & 55 & 70,5 & 23 & 29,5 \\
\hline $\begin{array}{l}\text { Cara memperbaiki nafsu } \\
\text { makan balita }\end{array}$ & 67 & 85,9 & 11 & 14,1 \\
\hline $\begin{array}{l}\text { Tujuan pemberian asupan } \\
\text { gizi seimbang }\end{array}$ & 72 & 92,3 & 6 & 7,7 \\
\hline $\begin{array}{l}\text { Manfaat Kartu Menuju } \\
\text { Sehat (KMS) }\end{array}$ & 42 & 53,8 & 36 & 46,2 \\
\hline $\begin{array}{l}\text { Bawah Garis Merah } \\
(\mathrm{BGM}) \text { pada KMS }\end{array}$ & 33 & 42,3 & 45 & 57,7 \\
\hline $\begin{array}{l}\text { Penyebab balita pendek } \\
\text { (stunting) }\end{array}$ & 35 & 44,9 & 43 & 55,1 \\
\hline
\end{tabular}

Berdasarkan tabel 3 diketahui bahwa sebagian besar $(92,3 \%)$ responden menjawab dengan benar pada pertanyaan pertanyaan "tujuan pemberian asupan gizi seimbang" dan 91\% responden pertanyaan "akibat dari kekurang gizi”. Selain itu dapat diketahui juga bahwa sebagian besar besar responden menjawab salah pada pertanyaan tentang "arti Bawah Garis Merah (BGM) pada KMS" dan pada pertanyaan contoh makanan "sumber zat besi" sebanyak $45(57,7 \%)$ responden. 
Berdasarkan scoring pengetahuan kemudian dikelompokkan dengan menggunakan cut off point nilai mean yaitu 8. Maka responden dikategorikan memiliki tingkat pengetahuan rendah jika skor $<8$ dan responden memiliki tingkat pengetahuan tinggi jika skor $\geq 8$.

Tabel 4. Distribusi Frekuensi Tingkat Pengetahuan Ibu Tentang Gizi di Kecamatan Labuan

\begin{tabular}{lcccc}
\hline \multirow{2}{*}{ Tingkat } & \multicolumn{2}{c}{ Kasus } & \multicolumn{2}{c}{ Kontrol } \\
\cline { 2 - 5 } Pengetahuan & $\mathrm{f}$ & $\%$ & $\mathrm{f}$ & $\%$ \\
\hline Rendah & 19 & 48,7 & 9 & 23,1 \\
Tinggi & 20 & 51,3 & 30 & 76,9 \\
\hline Total & 39 & 100 & 39 & 100 \\
\hline Berdasarkan & tabel & 4 & diketahui & bahwa \\
responden yang memiliki tingkat pengetahuan \\
rendah terbanyak pada balita kelompok kasus \\
$\begin{array}{l}\text { sebesar 48,7\% } \\
\text { kontrol 23,1\% }\end{array}$
\end{tabular}

\section{Sanitasi}

Tabel 5. Distribusi Frekuensi Sanitasi Rumah (Jamban dan Sumber Air) di Kecamatan Labuan

\begin{tabular}{lcccc}
\hline \multirow{2}{*}{ Variabel } & \multicolumn{2}{c}{ Kasus } & \multicolumn{2}{c}{ Kontrol } \\
\cline { 2 - 5 } & F & \% & f & \% \\
\hline $\begin{array}{l}\text { Kepemilikan } \\
\text { Jamban } \\
\text { Tidak }\end{array}$ & 15 & 38,5 & 6 & 15,4 \\
Ya & 24 & 61,5 & 33 & 84,6 \\
\hline Total & 39 & 100 & 39 & 100 \\
\hline Sumber Air & & & & \\
Tidak Layak & 6 & 15,3 & 0 & 0 \\
Layak & 33 & 84,7 & 39 & 100 \\
\hline Total & 39 & 100 & 39 & 100 \\
\hline
\end{tabular}

Berdasarkan tabel 5 diketahui bahwa responden yang tidak memiliki jamban sehat terbanyak pada balita kelompok kasus (stunting) sebesar 38,5\% sedangkan pada kelompok kontrol yang tidak memiliki jamban sehat hanya $15,4 \%$.

Selain itu dapat diketahui juga bahwa responden yang tidak memiliki sumber air yang layak terdapat di kelompok kasus yaitu 15,3\% sedangkan pada kelompok konrol tidak ada responden yang tidak memiliki sumber air yang layak $(0 \%)$.

1. Hubungan Karakteristik Balita (Jenis Kelamin, ASI Eksklusif, BBLR dan Imunisasi Dasar) Dengan Kejadian Stunting

Proporsi balita yang tidak mendapatkan ASI Eksklusif dan mengalami stunting $(38,4 \%)$ hampir sama dengan balita yang tidak ASI Eksklusif dan tidak mengalami stunting/normal (35,9\%). Secara statistik tidak terdapat hubungan yang bermakna antara ASI Eksklusif dengan kejadian stunting karena $p$-value $(0,815)>\alpha(0,05)$.

Proporsi balita yang mengalami Berat Badan Lahir Rendah (BBLR) dan mengalami stunting $(30,7 \%)$ jauh lebih banyak dibandingkan dengan balita yang BBLR namun tidak mengalami stunting/normal $(3,8 \%)$. Secara statistik terdapat hubungan yang bermakna antara BBLR dengan kejadian stunting pada balita karena $p$-value $(0,001)<$ $\alpha \quad(0,05)$. Proporsi balita yang tidak memperoleh imunisasi dasar dan mengalami stunting $(15,4 \%)$ tiga kali lebih banyak dibandingkan dengan bayi yang tidak memperoleh imuniasasi namun tidak mengalami stunting/normal $(5,1 \%)$. Secara statistik tidak terdapat hubungan yang bermakna antara status imunisasi dasar dengan kejadian stunting pada balita karena $p$ value $(0,263)>\alpha(0,05)$.

\section{Hubungan Tingkat Pengetahuan Ibu dengan Kejadian Stunting}

Proporsi ibu yang memiliki tingkat pengetahuan rendah dan balitanya mengalami stunting $(48,7 \%)$ dua kali lebih banyak dibandingkan dengan ibu yang memiliki tingkat pengetahuan rendah namun balitanya tidak mengalami stunting/normal (23,1\%). Secara statistik terdapat hubungan yang bermakna antara tingkat pengetahuan ibu tentang gizi dengan kejadian stunting pada balita karena $p$-value $(0,018)<\alpha(0,05)$. 
Tabel 6. Analisis Bivariat HubunganKarakteristik Balita, Pengetahuan ibu dan Sanitasi Terhadap Kejadian Stunting Pada Balita di Kecamatan Labuan, Pandeglang

\begin{tabular}{|c|c|c|c|c|c|c|c|c|}
\hline \multirow{2}{*}{ Karakteristik } & \multicolumn{2}{|c|}{ Kasus } & \multicolumn{2}{|c|}{ Kontrol } & \multicolumn{2}{|c|}{ Total } & \multirow{2}{*}{ Nilai p } & \multirow{2}{*}{$\begin{array}{c}\text { OR } \\
95 \% \mathrm{CI}\end{array}$} \\
\hline & $\mathbf{F}$ & $\%$ & $\mathbf{F}$ & $\%$ & $\mathbf{F}$ & $\%$ & & \\
\hline \multicolumn{9}{|l|}{ ASI Eksklusif } \\
\hline - Tidak & 15 & 38,4 & 14 & 35,9 & 29 & 37,2 & \multirow{2}{*}{0,815} & \multirow{2}{*}{$\begin{array}{c}1,116 \\
(0,445-2,797)\end{array}$} \\
\hline$-\mathbf{Y a}$ & 24 & 61,6 & 25 & 64,1 & 49 & 62,8 & & \\
\hline BBLR & & & & & & & \multirow{3}{*}{0,000} & \multirow{3}{*}{$\begin{array}{c}2,393 \\
(1,804-3,174)\end{array}$} \\
\hline$-\mathbf{Y a}$ & 12 & 30,7 & 0 & 0 & 12 & 15,3 & & \\
\hline - Tidak & 27 & 69,3 & 39 & 100 & 66 & 84,7 & & \\
\hline \multicolumn{9}{|l|}{ Imunisasi Dasar } \\
\hline - Tidak & 6 & 15,4 & 2 & 5,1 & 8 & 10,3 & \multirow[t]{2}{*}{0,263} & 3,364 \\
\hline - Ya & 33 & 84,6 & 37 & 94,9 & 70 & 88,7 & & $(0,635-17,827)$ \\
\hline \multicolumn{9}{|l|}{ Pengetahuan Ibu } \\
\hline - Rendah & 19 & 48,7 & 9 & 23,1 & 28 & 35,9 & \multirow[t]{2}{*}{0,018} & 3,167 \\
\hline - Tinggi & 20 & 51,3 & 30 & 76,9 & 50 & 64,1 & & $(1,195-8,389)$ \\
\hline \multicolumn{9}{|l|}{ Kepemilikan Jamban } \\
\hline - Tidak Ada Jamban & 15 & 38,5 & 6 & 15,4 & 29 & 24,8 & \multirow[t]{2}{*}{0,022} & 3,438 \\
\hline - Ada Jamban & 24 & 61,5 & 33 & 84,6 & 57 & 75,2 & & $(1,164-10,152)$ \\
\hline \multicolumn{9}{|l|}{ Sumber Air } \\
\hline - Tidak Layak & 6 & 15,3 & 0 & 0 & 6 & 5,1 & \multirow[t]{2}{*}{0,011} & \multirow{2}{*}{$\begin{array}{c}2,182 \\
(1,697-2,805)\end{array}$} \\
\hline - Layak & 33 & 84,7 & 39 & 100 & 72 & 94,9 & & \\
\hline
\end{tabular}

\section{Hubungan Sanitasi (Kepemilikan Jamban dan Sumber Air) dengan Kejadian Stunting}

Proporsi keluarga yang tidak memiliki jamban sehat dan balitanya mengalami stunting $(38,5 \%)$ dua kali lebih banyak dibandingkan dengan keluarga yang tidak memiliki jamban namun balitanya tidak mengalami stunting/normal $(15,4 \%)$. Secara statistik terdapat hubungan bermakna antara kepemilikan jamban sehat dengan kejadian stunting pada balita karena $p$-value $(0,022)<\alpha$ $(0,05)$. Proporsi keluarga yang tidak memiliki sumber air bersih dan balitanya mengalami stunting $(15,3 \%)$ jauh kali lebih banyak dibandingkan dengan keluarga yang tidak memiliki jamban namun balitanya tidak mengalami stunting/normal. Secara statistik terdapat hubungan yang bermakna antara kepemilikan jamban sehat dengan kejadian stunting pada balita karena $p$-value $(0,011)<\alpha$ $(0,05)$.

\section{Pembahasan}

1. Hubungan Karakteristik Balita (ASI Eksklusif, BBLR dan Imunisasi Dasar) dengan Kejadian Stunting Pada Balita

ASI memiliki banyak sekali keuntungan untuk bayi, yaitu mendapatkan status gizi optimal, meningkatkan kemampuan kognitif, mengurangi risiko kegemukan, pencegahan terhadap infeksi, mengurangi risiko terhadap alergi, dan menurunkan risiko morbiditas pada anak (Almatsier, 2011). ASI eksklusif sangat berpengaruh pada status gizi anak. Namun penelitian ini menunjukkan bahwa tidak ada hubungan signifikan antara ASI Eksklusif dengan kejadian stunting pada balita di Kecamatan Labuan. Hal ini sejalan dengan penelitian yang dilakukan oleh Paramashanti pada tahun 2015 bahwa pemberian ASI Eksklusif tidak berhubungan dengan stunting pada anak. Dari hasil penelitian ini diketahui bahwa pada kelompok kasus maupun kontrol, balita yang mendapatkan ASI Eksklusif memiliki presentase yang hampir sama yaitu $61,6 \%$ pada kelompok kasus dan $64,1 \%$ pada kelompok kontrol. Hal ini menunjukkan bahwa walaupun balita mendapatkan ASI Eksklusif namun mengalami stunting 
dikarenakan pemberian ASI Eksklusif bukanlah merupakan satu-satunya faktor yang mempengaruhi kejadian stunting pada balita tapi banyak faktor lainnya yang juga mempengaruhi seperti kualitas Makanan Pendamping ASI (MP ASI), kecukupan asupan gizi yang diberikan kepada anak setiap hari dan status kesehatan anak (Setiawan dkk, 2018).

Berat badan sangat mudah dipengaruhi oleh keadaan mendadak, seperti terserang infeksi atau diare, konsumsi makanan yang menurun. Ukuran tubuh pada saat lahir mencerminkan produk proses pertumbuhan janin yang terjadi selama masa kehamilan. WHO mendefinisikan Berat Badan Lahir Rendah (BBLR) yaitu <2500gr. Bayi baru lahir dapat memiliki berat <2500gr karena mengalami kelahiran premature atau lahir dengan usia kehamilan kurang dari 37 minggu. Dari penelitian ini diketahui bahwa persentase responden yang mengalami Berat Badan Lahir Rendah (BBLR) pada anak balita terdapat pada kelompok balita yang mengalami stunting yaitu 30,7\% sedangkan pada kelompok control tidak ada yang anak balitanya mengalami BBLR. Penelitian ini menunjukkan adanya hubungan yang signifikan antara kejadian BBLR dengan kejadian stunting pada balita di Kecamatan Labuan dengan nilai OR sebesar 2,393 (CI $95 \%: 1,804-3,174)$ artinya balita yang mengalami BBLR akan 2,393 kali lebih berisiko mengalami stunting dibandingkan dengan balita yang tidak mengalami BBLR. Hasil penelitian ini sejalan dengan penelitian yang dilakukan Paudel di Nepal bahwa Bayi dengan berat badan lahir rendah memiliki risiko 4,4 kali lebih besar untuk menjadi stunting (Paudel, 2012). Berat badan lahir bayi sangat dipengaruhi oleh gizi ibu selama kehamilan. Status gizi ibu hamil yang buruk dapat mempengaruhi perkembangan janin dan gangguan pertumbuhan dalam kandungan sehingga dapat menghasilkan berat badan lahir yang rendah (WHO, 2014). Berat lahir memiliki dampak yang besar terhadap pertumbuhan anak dan perkembangan anak.
Bayi lahir dengan berat lahir rendah dapat berisiko tinggi pada morbiditas, kematian, penyakit infeksi, kekurangan gizi dan stunting (Wiyogowati, 2012). Oleh karena itu penting untuk memastikan kecukupan asupan gizi ibu selama masa kehamilan untuk mencegah terjadinya Berat Badan Lahir Rendah (BBLR) yang akan berakibat stunting pada masa pertumbuhannya.

Penelitian ini menunjukkan tidak ada hubungan signifikan antara pemberian imunisasi dasar dengan kejadian stunting pada balita di Kecamatan Labuan. Hasil ini sejalan dengan penelitian yang dilakukan Anisa (2012) di Depok yang menyatakan bahwa tidak ada hubungan yang bermakna antara status imunisasi dasar dengan kejadian stunting. Begitu juga dengan penelitian yang dilakukan oleh Setiawan di Padang, bahwa tidak ada hubungan yang signifikan antara status imunisasi dasar dengan kejadian stunting (Setiawan dkk, 2018). Diketahui pada penelitian ini bahwa pada kelompok kasus dan kontrol sebagian besar balita mendapatkan imunisasi dasar. Dari data ini terlihat bahwa tingkat kesadaran ibu balita untuk memberikan imunisasi dasar kepada balitanya sudah tinggi dan tidak berhubungan dengan kejadian stunting pada balitanya dikarenakan ada faktor lain yang lebih dominan seperti asupan makanan yang kurang bergizi sehingga menurunkan daya tahan tubuh dan rentan terkena penyakit.

\section{Hubungan Tingkat Pengetahuan Ibu dengan Kejadian Stunting}

Pengetahuan atau kognitif merupakan domain yang sangat penting untuk terbentuknya tindakan seseorang (overt behavior) (Notoatmodjo, 2010). Pengetahuan gizi adalah sesuatu yang diketahui tentang makanan dalam hubungannya dengan kesehatan optimal. Penelitian ini menunjukkan bahwa ada hubungan signifikan antara tingkat pengetahuan ibu balita tentang gizi dengan kejadian stunting pada balita di Kecamatan 
Labuan dengen nilai OR sebesar 3,167 yang artinya ibu yang memiliki tingkat pengetahuan rendah tentang gizi akan 3,167 (CI 95\% : 1,195-8,389) kali lebih berisiko menyebabkan stunting pada balitanya dibandingkan dengan ibu yang memiliki pengetahuan tinggi.

Hasil penelitian ini sejalan dengan penelitian Ni'mah dan Nadhiroh (2015) di Surabaya dan penelitian Yulestari (2013) yang menyatakan bahwa pengetahuan ibu merupakan factor yang berhubungan kejadian stunting. Pada tabel 6 variabel Pengetahuan, dapat dilihat bahwa ibu balita pada kelompok kasus memiliki tingkat pengetahuan gizi yang lebih rendah daripada ibu balita kelompok kontrol. Hal ini menunjukkan bahwa rendahnya pengetahuan ibu tentang gizi mempengaruhi kejadian stunting pada balita. Ibu memegang peran sangat penting dalam pemilihan menu makanan bergizi untuk keluarga. Rendahnya pengetahuan ibu tentang gizi dapat menyebabkan kurangnya kualitas gizi makanan untuk keluarga khususnya makanan balita.. Hal ini tentunya akan berpengaruh terhadap kurangnya asupan balita yang dapat menghambat tumbuh kembangnya di masa golden age.

\section{Hubungan Sanitasi (Kepemilikan Jamban dan Sumber Air) dengan Kejadian Stunting}

Penelitian ini menunjukkan terdapat hubungan signifikan antara kepemilikan jamban sehat dengan kejadian stunting pada balita di Kecamatan Labuan dengan nilai OR sebesar 3,438 (CI 95\% : 1,164-10,152) artinya keluarga yang tidak memiliki jamban sehat akan 3,438 kali lebih berisiko terjadi stunting pada balitanya daripada keluarga yang memiliki jamban sehat. Hasil penelitian ini sejalan dengan penelitian Wiyogowati Tahun 2012 yang menyatakan ada hubungan bermakna antara sanitasi dasar degan kejadian stunting. Begitu juga dengan penelitian Adiyanti dan Besral (2014) yang menyatakan bahwa terdapat hubungan yang bermakna antara jenis jamban dengan kejadian stunting pada baduta. Pada tabel 6 variabel kepemilikan jamban sehat, dapat dilihat bahwa pada kelompok kasus (stunting) terdapat 38,5\% keluarga tidak memiliki jamban yang sehat sedangkan pada kelompok kontrol hanya $15,4 \%$ keluarga yang tidak memiliki jamban sehat. Perilaku Buang Air Besar Sembarangan (BABS) dikarenakan tidak memiliki fasilitas jamban sehat sangat erat kaitannya dengan tingginya angka kejadian diare yang dapat mempengaruhi tumbuh kembang balita bahkan bahkan mengakibatkan kematian. Oleh karena itu penting bagi setiap keluarga agar memiliki jamban untuk menjaga kesehatan keluarganya.

Penelitian ini menunjukkan terdapat hubungan signifikan antara sumber air dengan kejadian stunting pada balita di Kecamatan Labuan. Keluarga yang memiliki sumber air yang tidak layak akan 2,182 (CI 95\%:1,6972,805 ) kali lebih berisiko terjadi stunting pada balitanya daripada keluarga yang memiliki sumber air yang layak. Hasil penelitian ini sejalan dengan penelitian Adiyanti M. dan Besral yang menyatakan bahwa terdapat hubungan yang bermakna antara akses air bersih dengan kejadian stunting pada baduta. Keluarga yang tidak akses air bersih 1,26 kali lebih berisiko terjadi stunting pada balitanya daripada keluarga yang tidak memiliki akses air bersih (Adiyanti dan Besral, 2014). Air merupakan sumber kehidupan makhluk hidup. Manusia membutuhkan air bersih untuk menunjang kehidupannya sehari-hari. Air yang tidak layak/tercemar tentunya berisiko menimbulkan berbagai penyakit seperti diare, typhus, hepatitis dan lain-lain. Oleh sebab itu penting bagi setiap keluarga memiliki sumber air bersih untuk menjaga kesehatan keluarga termasuk balitanya agar dapat tumbuh dan berkembang secara optimal.

\section{Kesimpulan}

Terdapat hubungan signifikan antara Berat Badan Lahir Rendah (BBLR), pengetahuan ibu tentang gizi, kepemilikan jamban sehat dan sumber air bersih terhadap kejadian stunting pada balita di Kecamatan 
Labuan Kabupaten Pandeglang. Saran kepada Puskesmas Kecamatan Labuan untuk melakukan edukasi kesehatan kepada ibu balita dan ibu hamil serta pemeriksaan secara berkala agar pertumbuhan bayi dalam kandungan dapat terpantau dengan baik sesuai usia kandungan. Selain itu perlu dilakukan kegiatan pemberdayaan masyarakat dalam hal kepemilikan jamban yang sehat dan sumber air yang bersih.

\section{Referensi}

[1]. Adiyanti, M. dan Besral. 2014. Pola Asuh Gizi, Sanitasi Lingkungan dan Pemanfaatan Posyandu Dengan Kejadian Stunting Pada Baduta Di Indonesia (Analisis Data Riskesdas 2010). Skripsi Fakultas Kesehatan Masyarakat, Universitas Indonesia Depok. lib.ui.ac.id/naskahringkas/2016-04/S55589Maya\%20Adiyanti [Diakses pada tanggal 6 Agustus 2019].

[2]. Almatsier, S. 2011. Prinsip Dasar Ilmu Gizi. PT Gramedia Pustaka Utama. Jakarta

[3]. Anisa, Paramitha. 2012. Faktor-Faktor Yang Berhubungan dengan Kejadian Stunting Pada Balita Usia 25-60 bulan Di Kelurahan Kalibaru Depok Tahun 2012. Skripsi Fakultas Kesehatan Masyaraskat, Universitas Indonesia Depok.

lib.ui.ac.id/file?file=digital/20320460-S-

Paramitha\%20Anisa.pdf [Diakses tanggal 22 maret 2019]

[4]. Fikadu, T., Assegid, S. \& Dube, L. 2014. Factor associated with stunting among children age 24 to 59 months in Meskan District, Gurage Zone, South Ethiopia: A case- control study. BMC Public Health, 14(800).

https://bmcpublichealth.biomedcentral.com/tr ack/pdf/10.1186/1471-2458-14-800. [Diakses tanggal 11 Agustus 2018]

[5]. Kemenkes RI. 2014. Riset Kesehatan Dasar Tahun 2013. Jakarta: Kemenkes RI.

[6]. Kemenkes, RI: Ditjen Kesmas 2018. Hasil Pemantauan Status Gizi Tahun 2017. Jakarta : Kemenkes RI.

[7]. Kemenkes, RI: Ditjen Kesmas 2017. Hasil Pemantauan Status Gizi Tahun 2016. Jakarta : Kemenkes RI.

[8]. Ni'mah, K. \& Nadhiroh, Siti Rahayu. 2015. Media Gizi Indonesia Vol.10 No.1 hlm.13-19. Faktor Yang Berhubungan Dengan Kejadian Stunting Pada Balita.https://e-
journal.unair.ac.id/MGI/article/view/3117/226

4. [Diakses tanggal 11 Agustus 2018].

[9]. Notoatmodjo, S. 2010. Ilmu Perilaku Kesehatan. Jakarta : Rineka Cipta.

[10]. Paramashanti, Bunga A., Hadi, H dan Gunawan IMA. 2015. Pemberian ASI Eksklusif tidak berhubungan dengan stunting pada anak 6-23 bulan di Indonesia. Jurnal Gizi dan Dietetik Indonesia Vol.3 No.3(2015). https://www.researchgate.net/publication/3 07531093 Pemberian_ASI_eksklusif tida k berhubungan dengan_stunting_pada an ak usia 6-23 bulan_di_Indonesia [Diakses tanggal 31 Juli 2019].

[11]. Paudel, R., Pradhan, B., dkk (2012). Risk factors for stunting among children: A community based case control study in Nepal. Kathmandu University Medical Journal, 10(3), 18-24. https://www.researchgate.net/profile/Bandan a Pradhan/publication/235716397_Risk_Fac to

rsfor_Stunting Among_Children_A_Comm unity_Based_Case_Control_Study in N Nepal lli nk s/57732be508aeeec3895419a5/RiskFactors-for-Stunting-Among-Children-ACommunity- Based [Diakses tanggal 17 Agustus 2018].

[12]. Setiawan, E., Machmud, R., dan Masrul. 2018). Faktor-Faktor Yang Berhubungan dengan Kejadian Stunting Pada Balita Usia 25-59 bulan di Puskesmas Andalas Kecamatan Padang Timur Kota Padang Tahun 2018. Jurnal Kesehatan Andalas, 2018, Vo.7, No.2. http://jurnal.fk.unand.ac.id [Diakses tanggal 22 Maret 2019].

[13]. WHO. 2014. WHA Global Nutrition Targets 2025 : Stunting Policy Brief. Geneva: World Health Organization. http://www.who.int/nutrition/topics/globaltar gets_stunting_policybrief.pdf. [Diakses tanggal 17 Agustus 2018].

[14]. Wiyogowati, C. 2012. Kejadian Stunting PadaAnak Berumur di Bawah Lima Tahun 05 Bulan di Provinsi Papua Barat Tahun 2010 (Analisis Data Riskesdas Tahun 2010). Skripsi Fakultas Kesehatan Masyarakat, Universitas Indonesia Depok.

[15]. Yulestari. 2013. Analisis Faktor-Faktor SosioEkonomi dan Lingkungan Terhadap Kejadian Stunting Pada Balita 10-59 Bulan di Pulau Jawa Tahun 2010 (Analisis Data Riskesdas 2010). Skripsi Fakultas Kesehatan Masyarakat, Universitas Indonesia Depok. 